\title{
Macrobotanical evidence (wood charcoal and seeds) from the Middle Palaeolithic site of El Salt, Eastern Iberia: Palaeoenvironmental data and plant resources catchment areas
}

\author{
Paloma Vidal-Matutano ${ }^{\mathrm{a}, \mathrm{b}, *}$, Guillem Pérez-Jordàc ${ }^{\text {, Cristo M. Hernández }}{ }^{\mathrm{d}}$, Bertila Galván ${ }^{\mathrm{d}}$ \\ a PREMEDOC Research Group, Universitat de València, Departament de Prehistòria, Arqueologia i Història Antiga, Blasco Ibáñez 28 , 46010 València, Spain \\ ${ }^{\mathrm{b}}$ Université Côte-d'Azur CEPAM, CNRS, France \\ ${ }^{\mathrm{c}}$ IJCI - 2015-25082. GI Arqueobiología, Instituto de Historia, CCHS-CSIC, Albasanz 26-28, 28037 Madrid, Spain \\ ${ }^{\mathrm{d}}$ U.D.I. de Prehistoria, Arqueología e Historia Antigua, Facultad de Geografía e Historia, Universidad de La Laguna, Campus de Guajara, 38071 La Laguna, Santa Cruz de \\ Tenerife, Spain
}

\section{A R T I C L E I N F O}

\section{Keywords:}

El Salt

Neanderthals

Charcoal analysis

Fruit-gathering

Fuel management

Landscape

\begin{abstract}
A B S T R A C T
Despite the current growing number of studies that focus on macrobotanical remains from Middle Palaeolithic contexts, plant use among hunter-gatherer societies remains unknown in many regions of Europe. Large-scale flotation of archaeological sediments has made it possible to recover a large amount of plant remains (fruits, seeds and wood) from units VIII, IX, Xa and Xb at El Salt, Eastern Iberia (49.2-52.3 ka BP). The combination of anthracological and carpological analyses has provided a more accurate picture of the Middle Palaeolithic landscape in the Serpis valley, as well as significant information about other possible uses of plants, not only as fuel, but for woodworking or food, for instance. A minimum of twenty different taxa have been identified among the plant remains. Charcoal analysis suggested that firewood was gathered from nearby sources $(<1 \mathrm{~km})$, with a predominance of black-scots pine woodlands (Pinus nigra-sylvestris) and maples (Acer sp.). The carpological data reveal the use of some woody taxa not documented in the anthracological record (Taxus baccata or yew) and the presence of few mineralised seeds whose origin remains unknown (Celtis australis or hackberry, Rubus cf. laciniatus or evergreen blackberry). These data have significant implications for the interpretation of plant economy among Neanderthal groups, reinforcing the importance of available woody resources in the surroundings for the subsistence of the group.
\end{abstract}

\section{Introduction}

The study of the subsistence practices of hunter-gatherer societies has traditionally focused on hunting, leaving the role of the plants unknown (Haws, 2004; Aura et al., 2005; Pryor et al., 2013; Bigga et al., 2015). This is partly due to taphonomic problems and those regarding the preservation of organic remains, in addition to the lack of recovered plant remains based on the assumption that they are only preserved in exceptional conditions (Madella et al., 2002; Badal et al., 2012b; Pryor et al., 2013; Martínez and Badal, 2018). In recent decades, the increasing application of systematic recovery methods by flotation of sediments has made it possible to perform more studies that focus on macrobotanical remains from Palaeolithic and Mesolithic contexts (Uzquiano, 1992; Théry-Parisot et al., 1996; Gale and Carruthers, 2000; Goren-Inbar et al., 2002; Théry-Parisot, 2002; Aura et al., 2005; Arsuaga et al., 2012; Badal et al., 2012a; Uzquiano et al., 2012;
Monteiro, 2013; Vidal-Matutano et al., 2015; Alcolea, 2016; Allué et al., 2016; Henry and Boboeuf, 2016; Vidal-Matutano, 2017; Badal and Martínez, 2017; Martínez and Badal, 2018; Vidal-Matutano et al., 2017a). More recently, the introduction of new archaeobotanical disciplines has led to the development of methodological advances in order to obtain essential information about different uses of plants, other than for fuel, among hunter-gatherer groups (Hardy and Garufi, 1998; Richards et al., 2000; Dominguez-Rodrigo et al., 2001; Madella et al., 2002; Albert, 2010; Cabanes et al., 2010; Hardy and Moncel, 2011; Henry et al., 2011; Albert et al., 2012; Hardy et al., 2012; Sistiaga et al., 2014; Rodríguez-Cintas and Cabanes, 2015; Estalrrich et al., 2017). In Iberia, although anthracological analyses in Middle Palaeolithic contexts are becoming increasingly frequent (Gale and Carruthers, 2000; Finlayson et al., 2008; Arsuaga et al., 2012; Badal et al., 2012a; Uzquiano et al., 2012; Vidal-Matutano et al., 2015; Allué et al., 2016; Vidal-Matutano, 2017; Zilhão et al., 2016; Vidal-Matutano

\footnotetext{
* Corresponding author at: PREMEDOC Research Group, Universitat de València, Departament de Prehistòria, Arqueologia i Història Antiga, Blasco Ibáñez 28, 46010 València, Spain.

E-mail address: paloma.vidal@uv.es (P. Vidal-Matutano).
} 
et al., 2017a, 2017b), there are still gaps that must be studied (VidalMatutano, 2016). In addition to this, few carpological remains have been recovered and identified in these chronologies where the only known assemblages from the Iberian Peninsula to date are the pine kernels from Gorham's Cave and Vanguard Cave (Gale and Carruthers, 2000; Metcalf, 1964) or the mineralised Celtis seeds from Cueva del Niño (García Moreno et al., 2014), fact possibly related to a lack of sampling.

In this paper we present the results of the analysis of macrobotanical remains recovered from units VIII, IX, Xa and $\mathrm{Xb}$ at El Salt, Eastern Iberia (49.2-52.3 ka BP). The main objective is to provide information about the use of plant resources during MIS 3 human occupations at El Salt, a Middle Palaeolithic site which has yielded significant information that contributes to a deeper knowledge of Neanderthal behaviour based on a multidisciplinary approach (Galván et al., 2014a). On the one hand, analysing fuel remains could shed light both on the local landscape that would have existed in the Serpis valley at that time and the areas that could have provided firewood resources. On the other hand, it is important to analyse the carpological remains that have been recovered in order to complement palaeoecological and palaeoeconomic data, as their presence may or may not be linked to the use of fuel.

\section{Regional setting and excavation method}

The site of El Salt is an open-air rock shelter located at $680 \mathrm{~m}$ a.s.l. in the mountainous region of Alicante, Eastern Iberia (Fig. 1). The Middle Palaeolithic sequence is represented by eight stratigraphic units dating between $60.7 \pm 8.9$ and $45.2 \pm 3.4$ ka BP (Galván et al., 2014b). A 38-metre high Palaeocene limestone wall formed at a thrust fault and covered with tufa and travertine gave refuge to the space occupied by humans at the bottom of the wall, which would have covered almost the entire excavated surface at times of maximum development. This deposit has been systematically excavated since 1986 with an integrated multidisciplinary approach based on obtaining a higher temporal resolution of analysis related to Neanderthal behaviour (Mallol et al., 2013b, 2013a; Galván et al., 2014b, 2014a; Garralda et al., 2014; Sistiaga et al., 2014; Machado and Pérez, 2016; Rodríguez-Cintas and Cabanes, 2015; Machado et al., 2016; Vidal-Matutano, 2017; VidalMatutano et al., 2017a). The stratigraphic sequence consists of a dense palimpsest originating from recurrent human occupations, during which several activities were carried out. These activities correspond to the generic model of "hearth-related assemblages" (Vaquero and Pastó,
2001), i.e. superimposed flat combustion features of various sizes (0.20-1 m diameter) associated with rich archaeological assemblages including faunal remains, lithic objects, limestone pebbles with usewear and wood-charcoal fragments. Excavation of subunit $\mathrm{Xb}$ has led to the identification of an initial division of the palimpsest deposit into several fine-grained analytical units called archaeosedimentary facies associations (henceforth, AFA). These units correspond to the highest possible temporal resolution achievable within the studied context (Machado and Pérez, 2016; Machado et al., 2016).

\subsection{Current climatic and plant formations data}

The climate in the study area is determined by the topography. Rainfall is high compared with the local environment, with values close to $500 \mathrm{~mm}$ per year and reaching $800 \mathrm{~mm}$ at the highest points (Serra Mariola or Font Roja) (López Gómez and Rosselló Verger, 1978). Alcoy, where both sites are located, is currently framed in the mesomediterranean bioclimatic belt with mean annual temperature or MAT $=14.5^{\circ} \mathrm{C}$ and a dry ombroclimate (mean annual precipitation or MAP $=479 \mathrm{~mm}$ ) (Rivas-Martinez, 1987).

Nowadays the Aleppo pine (Pinus halepensis) is the predominant woody taxa in the region, followed by evergreen oaks (Quercus coccifera, Quercus rotundifolia) and legumes (Ulex parviflorus, Genista scorpius), terebinth (Pistacia terebinthus), mastic (Pistacia lentiscus), Mediterranean buckthorn (Rhamnus alaternus), blackthorn (Prunus spinosa), hawthorn (Crataegus monogyna) and elmleaf blackberry (Rubus ulmifolius). In the riverbank areas, poplar trees (Populus alba) and elms (Ulmus minor) are frequent. The presence of a mixed relict forest of Eurosiberian plant formations in the nearby mountain range of Font Roja should be pointed out, where taxa such as deciduous oaks (Quercus faginea, Quercus pubescens), ash (Fraxinus ornus), maple (Acer opalus subsp. granatense), whitebeam (Sorbus aria and Sorbus torminalis) and yew (Taxus baccata) are present (Costa et al., 2005; Serra Laliga and Soler, 2011). Evidence of relict formations of yew are also present in the higher altitude areas of Serra Mariola mountain range (Gualda Gómez, 1988; Costa et al., 2005).

\section{Materials and methods}

\subsection{Sampling method}

During the archaeological field seasons carried out between 2000 and 2012 all the sediment excavated from units VIII, IX and Xa was

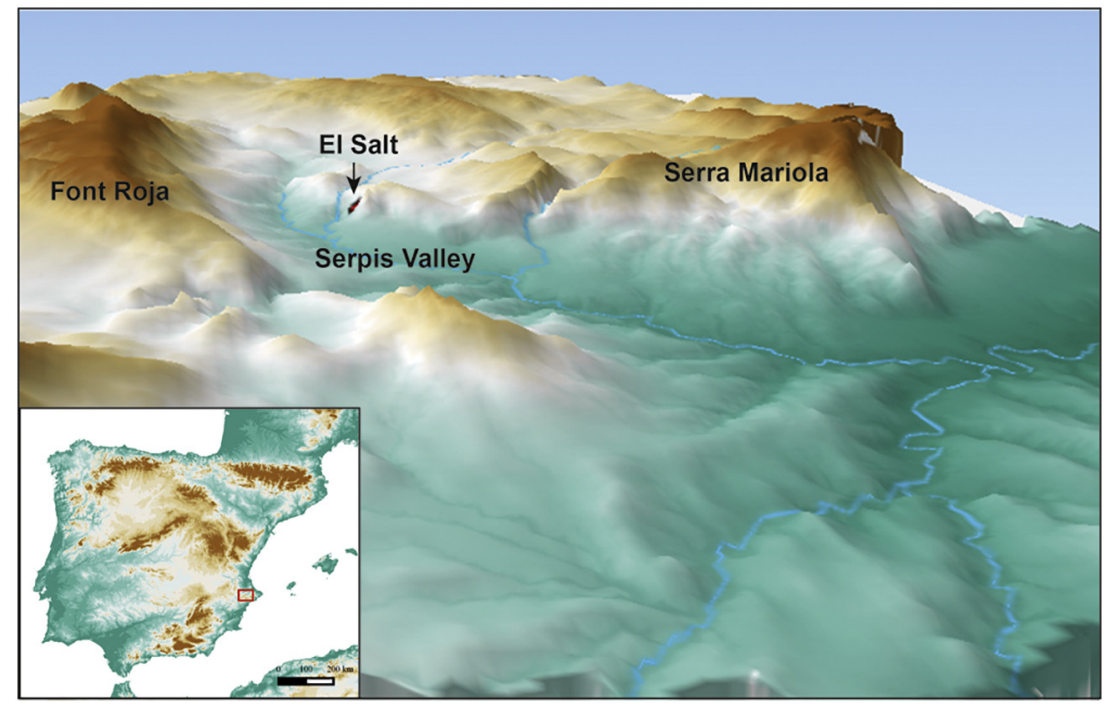

Fig. 1. Geographic location of the Middle Palaeolithic site of El Salt in the Iberian Peninsula and the Prebaetic System. The 3D map shows the Serpis valley and the mountain ranges of Font Roja and Mariola. 
processed by flotation and water sieving using 5 and $2 \mathrm{~mm}$ sieves. With regard to unit $\mathrm{Xb}$, systematic flotation of the sediments has been carried out using smaller mesh sizes since 2013. Thus, the denser remains that do not float were collected using a $1 \mathrm{~mm}$ mesh positioned inside the tank, while the flots were collected onto a $0.25 \mathrm{~mm}$ external mesh (Vidal-Matutano, 2016).

\subsection{Charcoal analysis}

Each charcoal fragment was fractured manually to provide transverse, tangential and radial sections for taxonomic identification using a Nikon Optiphot-100 bright/dark field incident light microscope with 50-500 $\times$ magnification. Botanical identification was performed with specialised plant anatomy atlases (Jacquiot et al., 1973; Schweingruber, 1976), in addition to the reference collection of modern charred woody taxa from the Department of Prehistory, Archaeology and Ancient History, University of Valencia. The spatial information relating to the current distribution of taxa has been obtained from the database of the Anthos Project (www.anthos.es). These data have been processed using GIS software (Quantum GIS v.2.10.1 "Pisa").

\subsection{Carpological analysis}

Plant remains are preserved through carbonisation and mineralisation and they were identified using a binocular microscope $(8-80 \times$ magnification). Identification was carried out by comparison with modern specimens from the seed reference collection of the Archaeobiology Lab of the Spanish National Research Council in Madrid (Spain), and by consulting specialised literature on plant anatomy. Botanical nomenclature follows Castroviejo (1986-2012).

\section{Results}

\subsection{Wood charcoal analysis results}

Previous studies have provided interesting data on anthracological assemblages from combustion structures at El Salt (Vidal-Matutano, 2017; Vidal-Matutano et al., 2017a), so this work focuses on scattered assemblages at the site. The scattered charcoal remains analysed from units VIII, IX, Xa and Xb at El Salt comprise a total of 4263 charcoal fragments and at least 17 taxa have been identified (Table 1). The difference between the sampling and recovery methods used in earlier and more recent field campaigns means that it is difficult to make a comparison between units. In fact, the sampling from units VIII, IX and $\mathrm{Xa}$, which correspond to the field seasons where coarser sieves were used, has provided fewer macrobotanical remains than unit $\mathrm{Xb}$, which was sampled more recently.

The most representative taxa in the part of the sequence of El Salt contemplated in this study are Pinus nigra-sylvestris (black-scots pine), Juniperus sp. (juniper) and Acer sp. (maple). This overall pattern is seen throughout these units, with a clear dominance of black-scots pine (values of 75-85\%), a lower frequency of juniper species (maximum values of $10 \%$ ) and a minor but constant presence of maples in all the units. There are few examples of evergreen and deciduous Quercus (oaks), and this is also the case with other taxa such as Buxus sempervirens (box), Fabaceae (the legume family), Rosaceae (the rose family), Pistacia sp. (cf. terebinth), Hedera sp. (ivy), Monocotyledoneae, Ephedra sp. (joint pine) and hygrophilous taxa such as Ulmus sp. (elm) and SalixPopulus (willow-poplar). With regard to the distinction between Pinus nigra and Pinus sylvestris, it is not possible to identify the exact species from anatomical criteria, so the nomenclature Pinus nigra-sylvestris has been used by many authors to refer to the identification of charred wood from these two possible species (Badal and Carrión, 2001; Badal et al., 2012a; Uzquiano et al., 2012; Roiron et al., 2013; Allué et al., 2016; Vidal-Matutano, 2017; Vidal-Matutano et al., 2017a, 2017b; Badal and Martínez, 2017).

\subsection{Seeds and fruits}

The seed and fruit remains recovered in the samples are not very frequent. A total of 7 taxa have been differentiated, although some of the samples present a large number of fruit fragments. The density of seeds and fruits is very low, ranging from 0.02 to 0.008 . (Table 2 and Fig. 2). Almost all the materials are charred. There are two taxa, Celtis australis (Mediterranean hackberry) and Rubus cf. laciniatus (evergreen blackberry), which are only mineralised, so there is some doubt about whether they may be present-day intrusions. There is also some uncertainty about the determination of Rubus cf. laciniatus, a taxon of unknown origin that is believed to have been introduced to Iberia (Monasterio-Huelin, 1999), although it's unknown at what point.

As it has been mentioned for wood charcoal remains, the coarser sieves used in older archaeological field seasons provided fewer carpological remains than those obtained in unit $\mathrm{Xb}$ with smaller mesh sizes. The charred material recovered includes a remarkable number of Acer sp. remains, which only come from unit $\mathrm{Xb}$. In subunit AFA 2, a considerable concentration of maple fruits was found inside combustion structure H57, together with wood charcoal fragments from this same taxon, which seems to point to its use as fuel although maple fruits could also serve as a food source (Kuhnlein and Turner, 1991). Other taxa that appear with a similar frequency are Juniperus sabina (savin juniper) and Fabaceae (legumes). Legumes are annual trees, shrubs or plants that usually grow in the same place each year. This fact facilitates their collection which usually takes place at the end of spring or beginnings of summer. Its seeds are rich in carbohydrates and proteins, making them an excellent food resource available before autumn, when Mediterranean forests produce most of their fruits. The seeds of this family may possibly belong to the genus Vicia or Lathyrus, but we don't have elements to confirm this determination. In any case, their presence at hunter-gatherer contexts is common (Aura et al., 2005; Martínez and Badal, 2018). More occasionally other taxa are found, such as Galium sp. (bedstraw) and Taxus baccata (yew).

\section{Discussion}

\subsection{Palaeoecological data}

The scattered charcoal assemblage from El Salt is characterised by the strong presence of cryophilous or medium-high Mediterranean mountain pines (black pine or scots pine) (Fig. 3). The dominance of Pinus nigra-sylvestris, with a proportion of $85-90 \%$ in some units, indicates that cryophilous pine forests must have played an important role in the vegetation of the studied region during MIS 3. These medium-high mountain pine forests would have been accompanied by a variable presence of junipers and/or savins, together with a sub-Mediterranean flora consisting of maples, evergreen/deciduous oaks and shrub taxa such as boxwood, legumes, joint-pine and terebinth. The occasional presence of charred ivy fragments in unit Xb (AFA 2) could be the result of accidental combustion due to this plant's ability to become entangled with other trees and shrubs in shady areas. In the valley floor, next to the Serpis river or in low or shady areas there would have been riverbank formations with willows and/or poplars and elms. It should be mentioned that 4 charred fragments of Olea europaea (wild olive) were identified in unit Xa and 6 charred fragments of Ficus carica (fig tree) were recorded in unit $\mathrm{Xb}$ (AFA 1 and AFA 2). In the case of the wild olive, this species is characteristic of warm Holocene contexts (Costa et al., 2005). Radiocarbon dating of olive wood-charcoal fragments at Palaeolithic sites has always yielded a Holocene chronology due to the percolation of fragments from more recent levels (Carrión et al., 2010; Badal et al., 2012b). With regard to Ficus carica, it is not a taxon that is frequently identified in Palaeolithic contexts of Western Europe, although carpological evidence of its presence has been recorded (Martínez and Badal, 2018). Thus, due to the absence of more data that support its presence in Palaeolithic period, we must be 
Table 1

Anthracological data from the scattered assemblages of units VIII, IX, Xa and Xb.

\begin{tabular}{|c|c|c|c|c|c|c|c|c|c|c|c|c|}
\hline Unit & \multicolumn{2}{|l|}{ VIII } & \multicolumn{2}{|l|}{ IX } & \multicolumn{2}{|l|}{$\mathrm{Xa}$} & \multicolumn{6}{|l|}{$\mathrm{Xb}$} \\
\hline \multicolumn{3}{|l|}{ Subunit } & & & & & \multicolumn{2}{|c|}{ AFA 1} & \multicolumn{2}{|c|}{ AFA 2} & \multicolumn{2}{|c|}{ AFA3 } \\
\hline Vol. litres & \multicolumn{2}{|l|}{112} & \multicolumn{2}{|l|}{120} & \multicolumn{2}{|l|}{237} & \multicolumn{2}{|c|}{223.5} & \multicolumn{2}{|l|}{294.7} & \multicolumn{2}{|l|}{305} \\
\hline Taxa & $\mathrm{N}$ & $\%$ & $\mathrm{~N}$ & $\%$ & $\mathrm{~N}$ & $\%$ & $\mathrm{~N}$ & $\%$ & $\mathrm{~N}$ & $\%$ & $\mathrm{~N}$ & $\%$ \\
\hline cf. Acer sp. & & & & & & & 2 & 0.25 & 2 & 0.13 & 5 & 0.65 \\
\hline Acer sp. & 10 & 2.95 & 10 & 6.45 & 43 & 7.30 & 77 & 9.52 & 110 & 6.88 & 148 & 19.17 \\
\hline Angiosperms & & & 4 & 2.58 & 9 & 1.53 & 14 & 1.73 & 24 & 1.50 & 12 & 1.55 \\
\hline cf. Buxus sempervirens & & & & & & & & & 2 & 0.13 & & \\
\hline Buxus sempervirens & 1 & 0.29 & 1 & 0.65 & & & 6 & 0.74 & 18 & 1.13 & 12 & 1.55 \\
\hline Conifers & 2 & 0.59 & 15 & 9.68 & 67 & 11.38 & 21 & 2.6 & 51 & 3.19 & 21 & 2.72 \\
\hline \multicolumn{13}{|l|}{ cf. Ephedra sp. } \\
\hline Ephedra sp. & & & & & 2 & 0.34 & 1 & 0.12 & & & 1 & 0.13 \\
\hline \multicolumn{13}{|l|}{ cf. Fabaceae } \\
\hline Fabaceae & & & 1 & 0.65 & & & 5 & 0.62 & 7 & 0.44 & & \\
\hline Ficus carica & & & & & & & 2 & 0.25 & 4 & 0.25 & & \\
\hline Hedera sp. & & & & & & & & & 5 & 0.31 & & \\
\hline Juniperus sp. & 5 & 1.47 & 11 & 7.10 & 26 & 4.41 & 6 & 0.74 & 16 & 1.00 & 3 & 0.39 \\
\hline Monocotyledoneae & 1 & 0.29 & & & 1 & 0.17 & & & & & & \\
\hline Olea europaea & & & & & 4 & 0.68 & & & & & & \\
\hline cf. Pinus nigra-sylvestris & 1 & 0.29 & & & 2 & 0.34 & 2 & 0.25 & 9 & 0.56 & 4 & 0.52 \\
\hline Pinus nigra-sylvestris & 313 & 92.33 & 105 & 67.74 & 407 & 69.10 & 656 & 81.09 & 1315 & 82.24 & 545 & 70.60 \\
\hline cf. Pistacia sp. & & & & & & & 2 & 0.25 & 1 & 0.06 & & \\
\hline Pistacia sp. & & & 1 & 0.65 & 1 & 0.17 & & & 1 & 0.06 & & \\
\hline cf. Prunus sp. & & & & & 1 & 0.17 & & & & & & \\
\hline cf. Quercus sp. & & & & & 2 & 0.34 & 1 & 0.12 & 1 & 0.06 & 2 & 0.26 \\
\hline Quercus sp. & 4 & 1.18 & 3 & 1.94 & 13 & 2.21 & 12 & 1.48 & 24 & 1.50 & 18 & 2.33 \\
\hline Quercus deciduous & 1 & 0.29 & & & 4 & 0.68 & 1 & 0.12 & 1 & 0.06 & & \\
\hline Quercus evergreen & & & & & 2 & 0.34 & & & 3 & 1.19 & 1 & 0.13 \\
\hline cf. Salix-Populus & & & & & & & & & 1 & 0.06 & & \\
\hline Salix-Populus & & & 4 & 2.58 & 5 & 0.85 & 1 & 0.12 & 3 & 0.19 & & \\
\hline Ulmus sp. & 1 & 0.29 & & & & & & & & & & \\
\hline Ulmaceae & & & & & & & & & 1 & 0.06 & & \\
\hline Total charcoal & 339 & 100 & 155 & 100 & 589 & 100 & 809 & 100 & 1599 & 100 & 772 & 100 \\
\hline Total taxa & 7 & & 8 & & 11 & & 10 & & 12 & & 6 & \\
\hline
\end{tabular}

Table 2

Carpological data from El Salt.

\begin{tabular}{|c|c|c|c|c|c|c|}
\hline Unit & Preservation & VIII & $\mathrm{Xa}$ & $\mathrm{Xb}$ & & \\
\hline Subunit & & & & AFA 1 & AFA 2 & AFA3 \\
\hline Vol. litres & & 112 & 237 & 223.5 & 294.7 & 305 \\
\hline Acer sp. fragments & Charred & & & 20 & 255 & \\
\hline Celtis australis & Mineralised & & & & 1 & \\
\hline Fabaceae & Charred & & & 2 & 3 & \\
\hline Galium sp. & Charred & & & & 2 & \\
\hline Juniperus sabina & Charred & 2 & 1 & & & \\
\hline Rubus cf. laciniatus & Mineralised & & & 1 & & \\
\hline Taxus baccata & Charred & & & & & 1 \\
\hline Parenchyma tissues & Charred & 7 & 7 & & & \\
\hline Undetermined & Charred & & 1 & & 1 & \\
\hline Total & & 2 & 2 & 3 & 7 & 1 \\
\hline Total fragments & & 7 & 7 & 20 & 255 & \\
\hline Density $\times 11$. & & 0.02 & 0.008 & 0.013 & 0.024 & 0.003 \\
\hline
\end{tabular}

cautious in its interpretation.

The plant record from El Salt, based on the macrobotanical remains recovered, is indicative of a local landscape characterised by predominantly supra-Mediterranean sub-humid conditions (MAT of 8-13 ${ }^{\circ} \mathrm{C}$ MAP of $600-1000 \mathrm{~mm}$ ). The climatic parameters contrast with those obtained for unit IV of Abric del Pastor, an earlier Middle Palaeolithic site (MIS 4/5) located $4 \mathrm{~km}$ away from El Salt, which shows predominantly semi-arid conditions consistent with a cooler and a more xeric climate during the development of MIS 4 period (Vidal-Matutano et al., 2015). Despite the fact that there is a great deal of homogeneity in the anthracological sequence from unit $\mathrm{Xb}$ to unit VIII at El Salt, certain differences can be identified in the rainfall pattern. Thus, the greater percentages of Acer sp. and Buxus sempervirens in unit $\mathrm{Xb}$, together with increasing Juniperus sp. values in units Xa and IX, indicate that the climate would have been more humid in the oldest part of the sequence (unit $\mathrm{Xb}$ ), which coincides with microfaunal data recovered from this unit (Fagoaga et al., 2017).

\subsubsection{Current climatic requirements of the identified flora}

The dominant species in the plant record of El Salt are not currently found in the study area but are characteristic of medium-high mountain areas in supra-Mediterranean and oro-Mediterranean bioclimatic belts (Ozenda, 1982; Rivas-Martinez, 1987). In order to discover the closest region that currently has similar climatic conditions to those of the Serpis valley during MIS 3, we have processed data on the current spatial distribution of some of the identified taxa. By processing these data in Quantum GIS we have been able to obtain different overlapping areas and to analyse whether there are any significant changes in the geographical distribution when species with specific altitude, humidity and temperature requirements are added. In this regard, the carpological data have added significant information to the palaeoecological approach. The homogeneous anatomical structure of Juniperus means that it cannot be identified at species level, so the identification of $J u$ niperus sabina (savin juniper) seeds makes it possible to confirm that at least this species was present, thus contributing highly detailed ecological information.

The overlapping areas generated result from selecting and/or eliminating taxa identified in the archaeological record in order to outline different possible ecological scenarios (Table 3). Overlapping area 1 has been obtained for Juniperus, Pinus nigra, Taxus baccata, Pistacia terebinthus and evergreen and deciduous Quercus species (Fig. 4a). 
$\mathbf{A}$
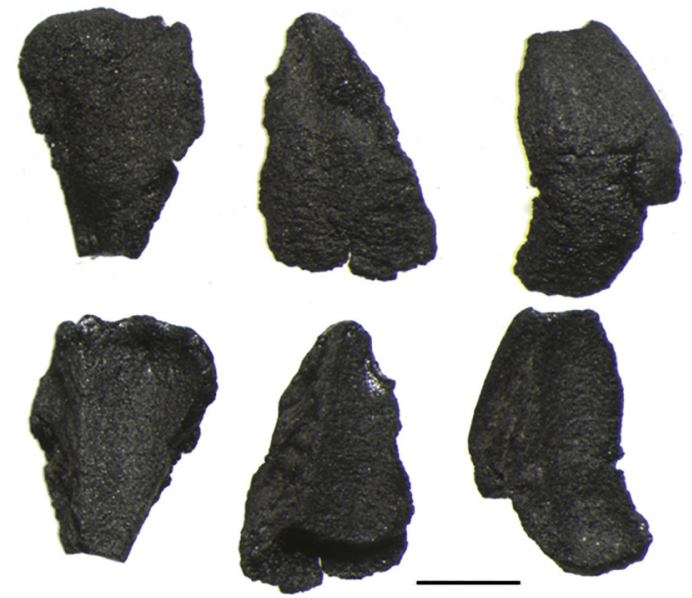
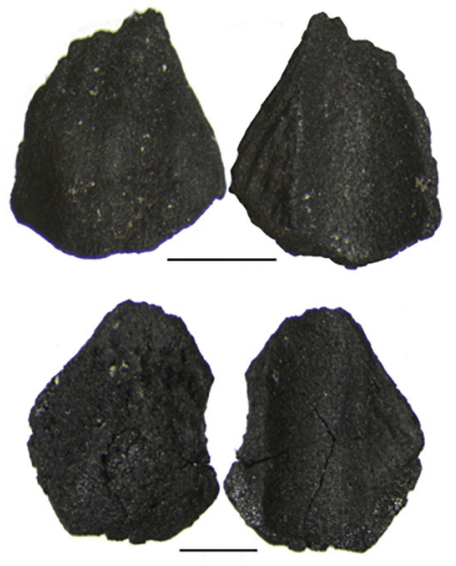

B

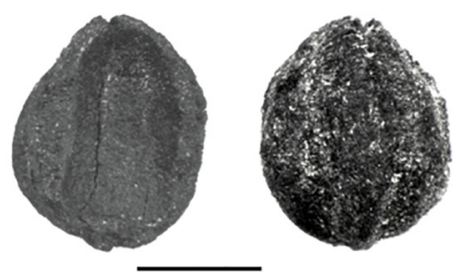

C

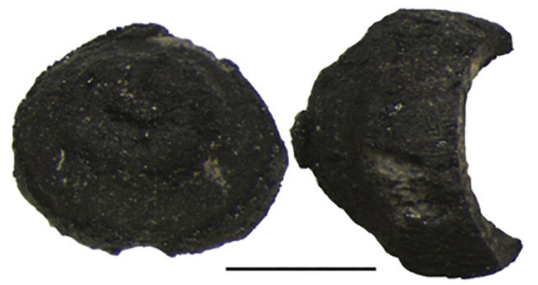

D
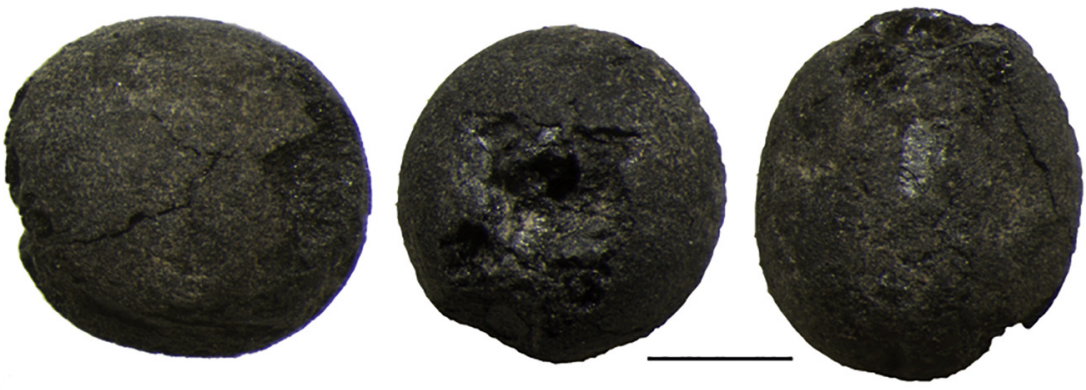

$\mathbf{E}$

F
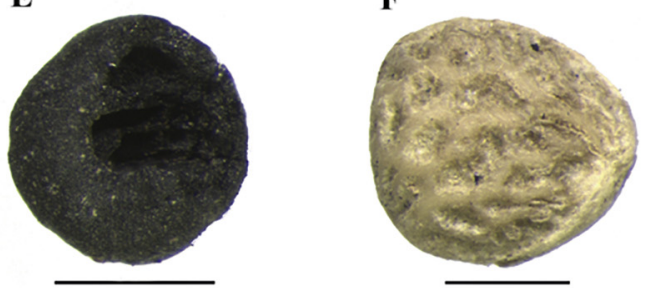

$\mathbf{G}$

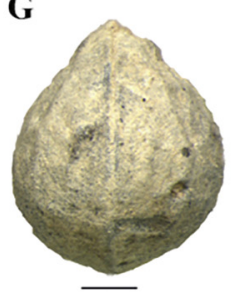

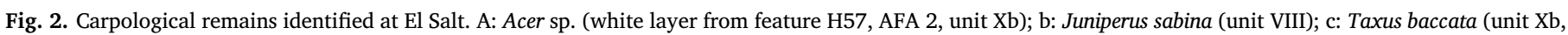

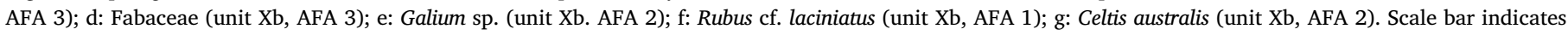
$1 \mathrm{~mm}$.

Overlapping area 2 includes the presence of Pinus sylvestris, Pinus nigra, Buxus sempervirens and species of the genus Acer (Fig. 4b). Overlapping area 3 includes the same taxa as overlapping area 2, but replacing Pinus sylvestris with Pinus nigra (Fig. 4c). Finally, overlapping area 4 covers the taxa included in overlapping area 2, but with the addition of evergreen and deciduous Quercus (Fig. 4d). The spatial analysis of these data has made it possible to detect small differences made by taxa with higher or lower temperature and humidity requirements (e.g. the notable distribution of overlapping area 2 in the Pyrenees due to the presence of boxwood, or the disappearance of points located at a higher altitude with the inclusion of Quercus species in overlapping area 4).
However, the maps generated indicate the prevalence of supra-Mediterranean bioclimatic conditions that are consistent with the palaeoecological results of the analysis of macrobotanical remains. In fact, the different ecological scenarios generated show the Sierra de Javalambre (Teruel) and the eastern Iberian System as the areas where the identified taxa are currently found. This mountainous region (1000-1500 m a.s.l.) lies in the supra-Mediterranean and oro-Mediterranean bioclimatic belts, with a MAT of $8-10{ }^{\circ} \mathrm{C}$ and a MAP of 500-700 mm (Rivas-Martinez, 1987; Costa et al., 2005). According to the macrobotanical data, these could have been the bioclimatic conditions in the Serpis valley region during the Middle Palaeolithic (Vidal- 


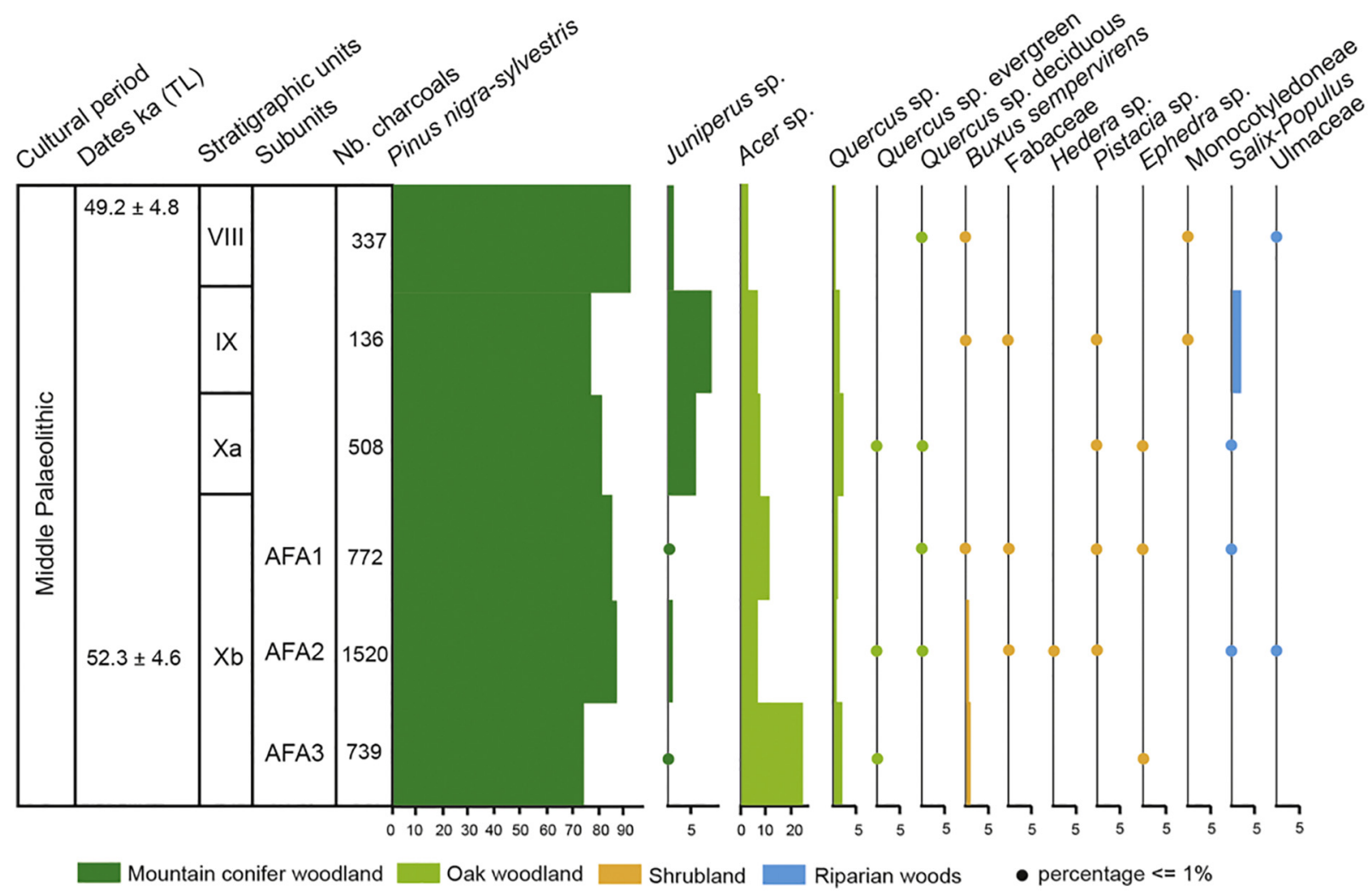

Fig. 3. Anthracological diagram from El Salt.

Table 3

Taxa used in the overlapping areas.

\begin{tabular}{lllll}
\hline Overlapping area & 1 & 2 & 3 & 4 \\
\hline Acer campestre & & $\mathrm{x}$ & $\mathrm{x}$ & $\mathrm{x}$ \\
Acer granatensis & & $\mathrm{x}$ & $\mathrm{x}$ & $\mathrm{x}$ \\
Acer monspessulanum & & $\mathrm{x}$ & $\mathrm{x}$ & $\mathrm{x}$ \\
Acer negundo & & $\mathrm{x}$ & $\mathrm{x}$ & $\mathrm{x}$ \\
Acer opalus & & $\mathrm{x}$ & $\mathrm{x}$ & $\mathrm{x}$ \\
Buxus sempervirens & $\mathrm{x}$ & & & $\mathrm{x}$ \\
Juniperus communis & $\mathrm{x}$ & & & \\
Juniperus oxycedrus & $\mathrm{x}$ & & & \\
Juniperus phoenicea & $\mathrm{x}$ & & & \\
Juniperus sabina & $\mathrm{x}$ & & & \\
Juniperus thurifera & $\mathrm{x}$ & $\mathrm{x}$ & & \\
Pinus nigra subsp. Arnold & $\mathrm{x}$ & $\mathrm{x}$ & & \\
Pinus nigra subsp. salzmanii & & $\mathrm{x}$ & $\mathrm{x}$ & \\
Pinus sylvestris & $\mathrm{x}$ & & & $\mathrm{x}$ \\
Pistacia terebinthus & $\mathrm{x}$ & & & \\
Quercus faginea & $\mathrm{x}$ & & & \\
Quercus ilex ballota & $\mathrm{x}$ & &
\end{tabular}

Matutano, 2016, 2017).

\subsection{Palaeoeconomic data}

\subsubsection{Contribution of seed remains to the palaeoeconomic approach}

Few seed remains were recovered at El Salt, although they provide significant information given the scarcity of known evidence of wild seeds in hunter-gatherer contexts (Gale and Carruthers, 2000; Weiss et al., 2004; Aura et al., 2005; Lev et al., 2005; Sievers, 2006; Weiss et al., 2008; García Moreno et al., 2014; Allué et al., 2015; Snir et al., 2015; Badal and Martínez, 2017; Martínez and Badal, 2018). The results presented here show the importance of performing a systematic and exhaustive flotation of the sediments to achieve optimum results (Vidal-Matutano, 2016).
Most of the carpological remains are charred, which is a basic condition to infer their relationship with anthropic activities. The carbonisation of the seeds indicates that they were exposed to fire either intentionally (to be processed for eating or disposed of in the fire) or unintentionally (accompanying firewood). Two taxa (Rubus cf. laciniatus and Celtis australis) are only mineralised, which leads to the question of whether their origin is anthropic. Some fruits, such as Celtis, are known for having a high carbonate content in the pericarp, which makes them resistant to decay (Cowan et al., 1997; Messager et al., 2010; Shillito and Almond, 2010). This property of Celtis has been seen as a reason for its abundance in some Pleistocene archaeological sites (Lev et al., 2005; Messager et al., 2010; García Moreno et al., 2014; Allué et al., 2015). However, as no charred remains of this fruit have been recovered yet, its relationship with human activities could be questioned, and it may be the result of modern contamination, percolation from Holocene levels at sites with an extensive sequence or introduction by birds (Sievers, 2006). Even so, it is noteworthy that abundant fragments of mineralised Celtis pericarps were found in the thin layers obtained from unaltered primary contexts of unit Xb (Mallol et al., 2013b).

The charred materials that could have been used as food by Neanderthal groups are maples seeds, legumes and juniper. Indeed, the presence of legumes in contexts of hunter-gatherer groups is common (Aura et al., 2005; Martínez and Badal, 2018) and they are a food resource found in Mediterranean forests. Juniperus and Acer are taxa that have been used for human consumption (Rivera-Núñez and Obón-deCastro, 1991; Kuhnlein and Turner, 1991), but when they appear associated with wood charcoal fragments the question arises as to whether the fruits were accidentally harvested or not and whether they were intended for human consumption.

Despite the fact that the carpological record is well preserved, the Acer sp. seeds recovered in the area of combustion structure H57 show a high degree of fragmentation (Fig. 2a). This hyper-fragmentation of the macrobotanical remains is consistent with that observed in the 


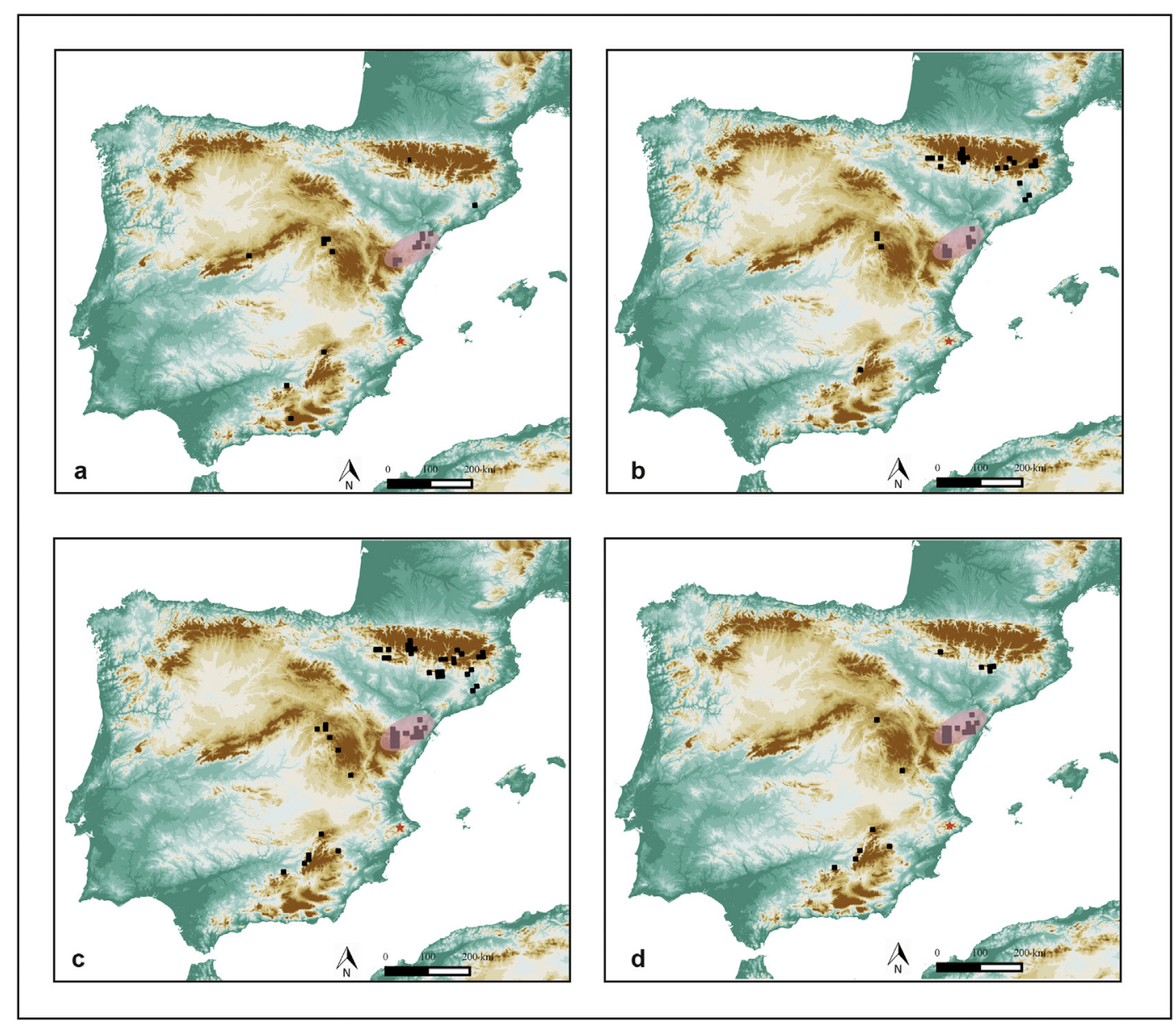

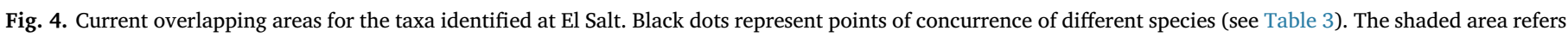
to the coincident region between the overlapping areas (Sierra de Javalambre-Gúdar, Teruel, and the eastern Iberian System).

anthracological assemblages of El Salt, where the overall distribution of charcoal fragments fits into two size categories: $2-4 \mathrm{~mm}$ and $1-2 \mathrm{~mm}$ (Vidal-Matutano et al., 2017a). This may be related to exposure of the remains to fire and/or to the occupation dynamics of the shelter. In fact, the configuration of the stratigraphic sequence of El Salt as a dense palimpsest of recurrent occupation events (Mallol et al., 2013a; Machado and Pérez, 2016; Machado et al., 2016; Vidal-Matutano, 2017) could explain the fact that the macrobotanical remains are affected by mechanical processes of anthropic origin (trampling, reworking) in addition to natural processes (freezing/thawing or drying/ humidity cycles) (Théry-Parisot et al., 2010).

Bearing in mind that much of the carpological record consists of taxa that are present in the anthracological assemblages from the site, it is feasible that these remains could have been thrown into the fire together with the fuel. However, there are certain considerations that are worthy of attention. Firstly, both Rubus cf. laciniatus and Celtis australis produce edible fruits that have traditionally been valued by human societies (Pardo-de-Santayana et al., 2007). Nevertheless, their presence should be interpreted with caution, as these taxa are easily mineralised and are not charred. Significant evidence comes from a fragment of yew fruit, as the use of this taxon as fuel has not been noted at any point in the sequence of El Salt (Vidal-Matutano, 2016). This contrasts with the anthracological information from Abric del Pastor, where few yew fragments were identified among the fuel used (VidalMatutano, 2015). The presence of this carpological remain only in unit $\mathrm{Xb}$ of El Salt raises the question of plants being collected for uses other than as fuel, e.g. the selection of woods with which to manufacture implements or handles for tools. In fact, yew wood is very strong and elastic, which makes it easy to work with (Uzquiano et al., 2015). This is why it was so highly valued in the past, as can be seen from its use in numerous Mesolithic and Neolithic bows from Northern Europe (Cattelain, 1997) or the yew tools recovered from the lakeside settlement of La Draga (Blanco et al., 2008). Recent evidence from Aranbaltza III (northern Iberia) point out to the presence of a Middle Palaeolithic wooden tool made of yew (Rios-Garaizar et al., 2018), reinforcing the importance of this species for woodworking. The charred yew fruit fragment from El Salt is a confirmation of its presence in the local environment, despite it was not being used for fuel. This may be related to the possibility that Neanderthal groups protected this tree in order to make use of it for other products: wood for tools, a natural poison due to its high taxine content (Pérez-Díaz et al., 2013), for medicinal uses (Cortés et al., 2000) or even as food (Rivera-Núñez and Obón-de-Castro, 1991). These last options must be evaluated since only one carpological remain is evidenced.

Finally, the observation of wood degradation patterns that occurred prior to charring followed by their quantitative analysis according to previous experimental studies revealed differences between the alteration degrees of the firewood used in the hearths, highlighting the existence of firewood acquisition criteria based on dead wood gathering by Neanderthal groups of Eastern Iberia and also suggesting smokerelated functions, e.g. the preservation of meat in view of a group migration, the treatment of hides, the repelling of mosquitoes or flies, among others (Vidal-Matutano et al., 2017a). In this regard, the recovery of 253 charred maple seed fragments within the ash layer of combustion feature $\mathrm{H} 57$ at El Salt has provided significant information about the state of the wood that was chosen as fuel (dead, mostly degraded black-scots pine together with the collection of dead maple branches at, at least, an incipient state of biodegradation). Furthermore, 


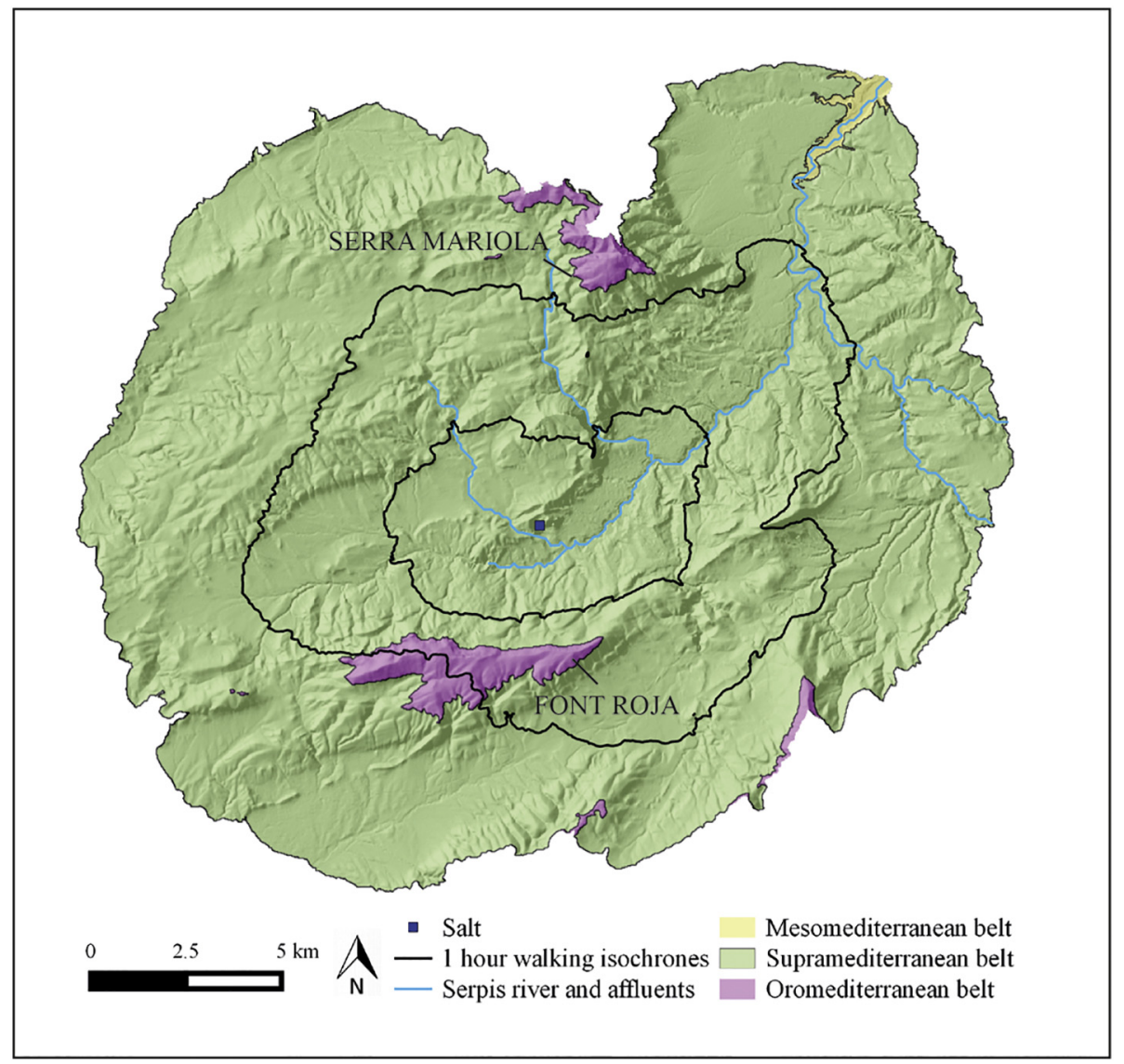

Fig. 5. Cost surface map with the isochrones (walking hours) from El Salt. Bioclimatic belts represented show its theoretical distribution based on simulated biogeographical conditions for MIS 3 period in the region (Vidal-Matutano and Pardo-Gordó, 2017).

the presence of these carpological remains could provide clues to the seasonal use of this hearth. According to the growth cycle of maple, the occupation event related to combustion structure 57 may have taken place during the autumn-winter period (Vidal-Matutano et al., 2017a). This evidence is a good example of the need to interrelate the presence of carpological and anthracological remains in order to obtain significant information about the use and management of plants.

\subsubsection{Plant resources management by Neanderthal groups}

Site catchment analysis (SCA) has been widely used to assess the interaction of human societies with the natural resources available in their surroundings (Jarman et al., 1972; Roper, 1979; Hodder and Orton, 1990). Despite the potential shown by this tool in the first model applied to catchment areas among hunter-gatherer groups in the area around Monte Carmelo (Vita-Finzi and Higgs, 1970), few studies have been published for Pleistocene contexts (Bailey and Davidson, 1983; Marín Arroyo, 2008). In our case, it is a good analytical tool for estimating the extent to which the composition of the local landscape influenced planned wood gathering activities.

One of the proposed approaches for achieving a more accurate calculation of catchment areas and distances from the site is to readjust the theoretical area on the basis of the topography. Thus, the area is delimited by isochrones or contour lines, making it possible to show the theoretical walking hours according to Naismith's rule (Jarman et al., 1972; Roper, 1979; Norman, 2004). In our case, the cumulative anisotropic cost of moving from El Salt to different geographical locations was calculated using a raster map containing simulated biogeographical conditions for the MIS 3 period in the region of the Serpis valley (VidalMatutano and Pardo-Gordó, 2017). The cost map generated for El Salt shows that it takes two walking hours to reach the theoretical distribution of the oro-Mediterranean bioclimatic belt (Font Roja's peak), and to the north it would be possible to reach part of the Sierra Mariola and the Serpis valley in this period of time, as there are no significant slopes (Fig. 5). However, these landscape analysis models are based on the current geomorphological features of a region, concealing the orographic changes that have taken place since the Pleistocene. Given that our intention is to define the optimal distribution of vegetation based on the identified macrobotanical remains, we have chosen to use two theoretical concentric circles relating to two levels of wood procurement (Fig. 6):

- Theoretical procurement within a radius of $1 \mathrm{~km}$ : the immediate vicinity of the site based on ethnographic data that suggest that dead wood is gathered within a radius of up to $1 \mathrm{~km}$ and green wood within a distance of 50-70 m (Alix and Brewster, 2004; Henry et al., 2009; Henry and Théry-Parisot, 2014). This distance from the site would depend mainly on the availability of Pinus nigra-sylvestris and Acer sp. wood in different states, i.e. dead, rotting, green or healthy wood.

- Theoretical procurement within a radius of $5 \mathrm{~km}$ : an area that was traditionally regarded as optimal for firewood gathering, equivalent to the territory covered in $1 \mathrm{~h}$ (Butzer, 1982; Badal and Heinz, 1991). Juniperus sabina would have been present in this area, predominantly occupying the oro-Mediterranean bioclimatic belt, possibly together with other species of the same genus ( $J$. communis, J. thurifera). Some species of Quercus would have been present in the region, with a greater abundance of deciduous Quercus sp. in more humid areas. Finally, some scantly represented taxa would have occupied riverside plant formations (ash, elm, willow, poplar) or valleys or shady areas (yew).

The analysis of firewood procurement, together with the hypothetical distribution of vegetation during MIS 3, reinforces the idea of the strategic location of the settlement in a rock shelter with quick, easy access to a variety of biotopes: supra-Mediterranean and oroMediterranean medium-high mountains, extensive plains in the Serpis 


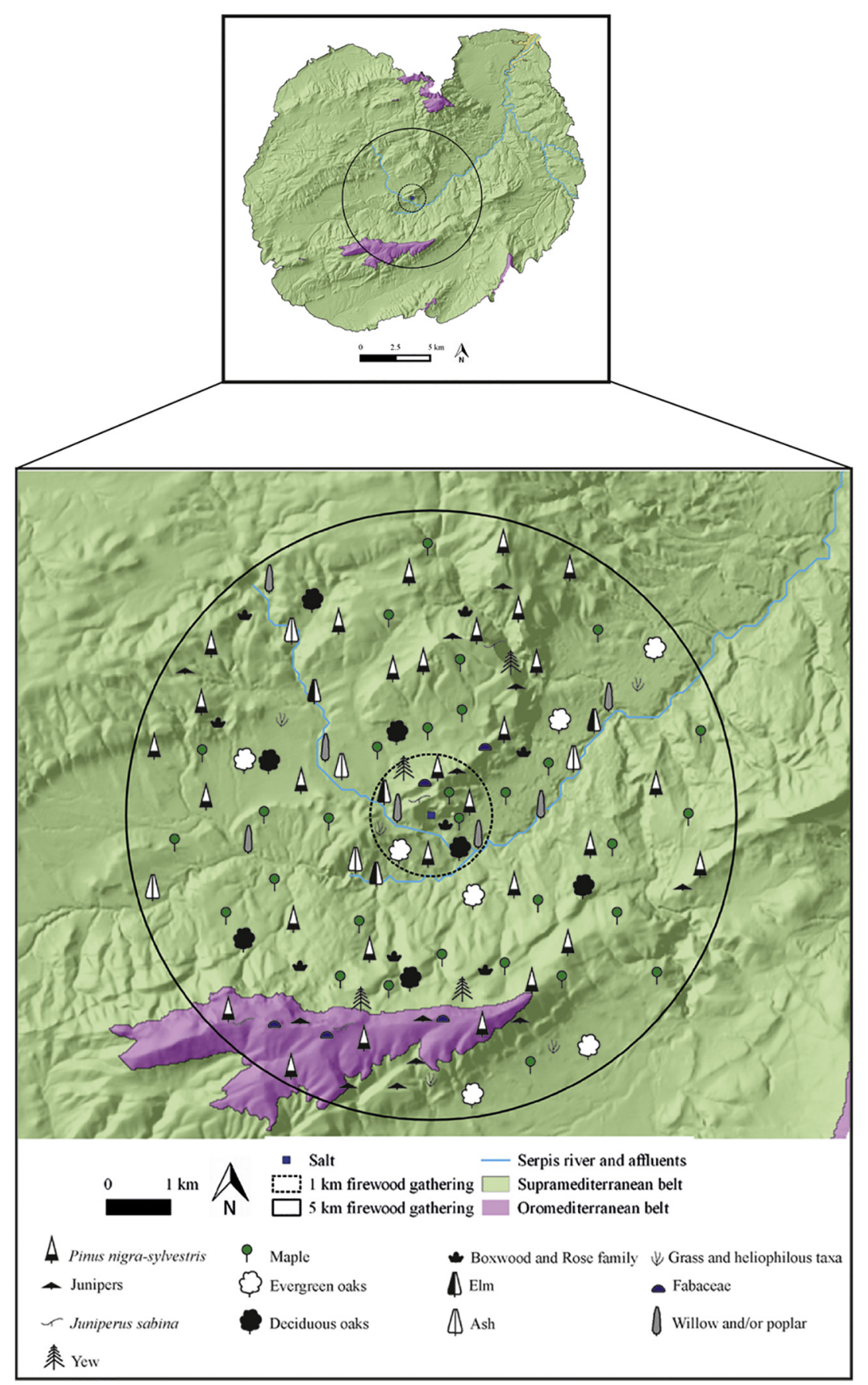

Fig. 6. Hypothetical plant distribution during MIS 3 human occupations in the Serpis valley, based on the anthracological data from El Salt. Taxa symbols are based on the codification used by De la Blache (1908).

valley and riverside plant formations. Availability, access and abundance of firewood in the local environment would certainly have been decisive factors in choosing this location for the settlement. The abundance of coniferous woods in the anthracological record contrasts with the lower frequency of other plant formations that are found further from the shelter, such as riverside vegetation. This lower proportion could be explained by the existence of sufficient dead pine and maple wood in the immediate vicinity of the shelter, which would avoid its inhabitants having to transport wood from greater distances. The theoretical distance of $1 \mathrm{~km}$ around El Salt seems to suggest the existence of various biotopes that could provide the taxonomical diversity seen in the macrobotanical analysis. Moreover, this radius of action is consistent with the "Principle of least effort" proposed by Shackleton and Prins (1992), where firewood collection activities would take place within a small radius that would only have been extended due to a scarcity of dead wood.

\section{Conclusions}

The data from the macrobotanical remains presented here have shed new light on the environmental conditions in Eastern Iberia during MIS 3 and the use and management of firewood resources by Neanderthal groups. Systematic flotation of sediments at El Salt has proven to be an effective method for recovering charcoal and seed fragments. The anthracological data suggest that the local plant landscape was characterised by the dominance of sub-humid supra-Mediterranean 
conditions (MAT $8-13^{\circ} \mathrm{C}$ and MAP $600-1000 \mathrm{~mm}$ ), similar to those currently found in the Sierra de Javalambre (Teruel) and the eastern Iberian system. Fuel gathering would have been a planned activity carried out mainly in local procurement areas. Site catchment analysis shows that wood collection activities could have been concentrated within a small radius of $1 \mathrm{~km}$, where the different biotopes found in the analysis of the macrobotanical remains would have been present. The theoretical distance of $1 \mathrm{~km}$ around the shelter is defined in relation to the ethnographic observations that indicate this radius for the procurement of dead wood and a smaller distance for collecting green wood. In this regard, previous anthracological studies carried out at El Salt from a palaeoeconomic perspective have pointed to the preferential use of dead wood by Neanderthal groups, a type of biomass that would have been readily available in the immediate vicinity of the site. The combination of anthracological and carpological analyses is fundamental, as it enables us to gain a better picture of the local climatic conditions at that time (e.g. identification of the species Juniperus sabina thanks to the recovery of endocarps). Moreover, the recovery of fruits from taxa that are absent in the anthracological record means that these plants may have been used for other purposes, e.g. wood working or food source (Taxus baccata). The application of systematic methods of recovering macrobotanical remains in other Middle Palaeolithic contexts will help to provide more knowledge about the dynamics of the local plant landscape and the way human groups interacted with plant resources.

\section{Acknowledgements}

This work was carried out with the financial support of a VALi $+d$ pre-doctoral grant (ACIF/2013/260) awarded to P. Vidal-Matutano. The archaeological research was funded under the Spanish Government projects HAR2012-32703 and HAR2015-68321-P (MICINN-FEDER/UE) and Direcció General de Cultura (Conselleria d'Educació, Cultura i Esports, Generalitat Valenciana). PVM is funded by the APOSTD Postdoctoral grant (APOST/2017/126, Generalitat Valenciana). GPJ has participated as part of his post-doctoral contract IJCI-2015-25082 funded by the Spanish Ministerio de Economía, Industria $y$ Competitividad. We would like to thank the ANTHOS Project (Fundación Biodiversidad and CSIC - Real Jardín Botánico) which allowed us the use of spatial information relating to the current distribution of taxa and the team from El Salt for their help with field sampling tasks. We are very grateful to the reviewers for helpful comments on the manuscript.

\section{References}

Albert, R., 2010. Hearths and plant uses during the Upper Palaeolithic period at Klissoura Cave 1 (Greece): the results from phytolith analyses. In: Eurasian Prehistory. 7. pp. 71-85.

Albert, R.M., Berna, F., Goldberg, P., 2012. Insights on Neanderthal fire use at Kebara Cave (Israel) through high resolution study of prehistoric combustion features: evidence from phytoliths and thin sections. Quat. Int. 247, 278-293.

Alcolea, M., 2016. Mesolithic fuel use and woodland in the Middle Ebro Valley (NE Spain) through wood charcoal analysis. Quat. Int. http://dx.doi.org/10.1016/j.quaint.2015. 11.029.

Alix, C., Brewster, K., 2004. Not all driftwood is created equal: wood use and value along the Yukon and Kuskowim Rivers, Alaska. Alaska J. Anthropol. 2, 48-65.

Allué, E., Cáceres, I., Expósito, I., Canals, A., Rodríguez, A., Rosell, J., Bermúdez de Castro, J.M., Carbonell, E., 2015. Celtis remains from the Lower Pleistocene of Gran Dolina, Atapuerca (Burgos, Spain). J. Archaeol. Sci. 53, 570-577.

Allué, E., Solé, A., Burguet-Coca, A., 2016. Fuel exploitation among Neanderthals based on the anthracological record from Abric Romaní (Capellades, NE Spain). Quat. Int. http://dx.doi.org/10.1016/j.quaint.2015.12.046.

Arsuaga, J.L., Baquedano, E., Pérez-González, A., Sala, N., Quam, R.M., Rodríguez, L., García, R., García, N., Álvarez-Lao, D.J., Laplana, C., Huguet, R., Sevilla, P., Maldonado, E., Blain, H.-A., Ruiz-Zapata, M.B., Sala, P., Gil-García, M.J., Uzquiano, P., Pantoja, A., Márquez, B., 2012. Understanding the ancient habitats of the lastinterglacial (late MIS 5) Neanderthals of central Iberia: Paleoenvironmental and taphonomic evidence from the Cueva del Camino (Spain) site. Quat. Int. 275, 55-75.

Aura, J., Carrión, Y., Estrelles, E., Jordà, G., 2005. Plant economy of hunter-gatherer groups at the end of the last Ice Age: plant macroremains from the cave of Santa Maira (Alacant, Spain) ca. 12000-9000 B.P. Veg. Hist. Archaeobotany 14, 542-550.

Badal, E., Carrión, Y., 2001. Del Glaciar al Interglaciar: los paisajes vegetales a partir de los restos carbonizados hallados en las cuevas de Alicante. In: Villaverde, V. (Ed.), De Neandertales a Cromañones: El inicio del poblamiento en las tierras valencianas. Servei de Publicacions. Universitat de València, pp. 21-40.

Badal, E., Heinz, C., 1991. Méthodes utilisées en Anthracologie pour l'étude de sites préhistoriques. BAR International Series 573. pp. 17-47.

Badal, E., Martínez, C., 2017. Different parts of the same plants. Charcoals and seeds from Cova de les Cendres (Alicante, Spain). Quat. Int. http://dx.doi.org/10.1016/j.quaint. 2016.12.020.

Badal, E., Villaverde, V., Zilhão, J., 2012a. Middle Palaeolithic wood charcoal from three sites in South and West Iberia: biogeographic implications. In: Badal, E., Carrión, Y., Macías, M., Ntinou, M. (Eds.), Wood and Charcoal. Evidence for Human and Natural History. 13. Saguntum-Extra, pp. 13-24.

Badal, E., Carrión, Y., Figueiral, I., Oliva Rodríguez-Ariza, M., 2012b. Pinares y enebrales. El paisaje solutrense en Iberia. In: Espacio, Tiempo y Forma. Serie I Prehistoria y arqueología 5. pp. 259-272.

Bailey, G.N., Davidson, I., 1983. Site exploitation territories and topography: two case studies from Palaeolithic Spain. J. Archaeol. Sci. 10, 87-115.

Bigga, G., Schoch, W.H., Urban, B., 2015. Paleoenvironment and possibilities of plant exploitation in the Middle Pleistocene of Schöningen (Germany). Insights from bo tanical macro-remains and pollen. J. Hum. Evol. 89, 92-104.

Blanco, E., Vasco, F., Abella, I., Cortés, S., 2008. Tejo y cultura: de la tradición etnobotánica a la farmacología científica. In: Annals de la Delegació de La Garrotxa de la Institució Catalana d'Història Natural. 4. pp. 63-78.

Butzer, K.W., 1982. Archaeology as Human Ecology: Method and Theory for a Contextual Approach. Cambridge University Press.

Cabanes, D., Mallol, C., Expósito, I., Baena, J., 2010. Phytolith evidence for hearths and beds in the late Mousterian occupations of Esquilleu cave (Cantabria, Spain). J. Archaeol. Sci. 37, 2947-2957.

Carrión, Y., Ntinou, M., Badal, E., 2010. Olea europaea L. in the North Mediterranean Basin during the Pleniglacial and the Early-Middle Holocene. Quat. Sci. Rev. 29, 952-968.

Castroviejo, S., 1986-2012. Flora ibérica 1-8, 10-15, 17-18, 21. Real Jardín Botánico. CSIC, Madrid.

Cattelain, P., 1997. Hunting during the Upper Paleolithic: bow, spearthrower, or both? In: Knecht, H. (Ed.), Projectile Technology. Springer, pp. 213-240.

Cortés, S., Vasco, F., Castro, E.B., 2000. El libro del tejo (Taxus baccata L.): un proyecto para su conservación. Arba.

Costa, M., Morla, C., Sainz (Eds.), 2005. Los bosques ibéricos: Una interpretación geobotánica. Planeta, Barcelona.

Cowan, M.R., Gabel, M.L., Jahren, A.H., Tieszen, L.L., 1997. Growth and biomineralization of Celtis occidentalis (Ulmaceae) pericarps. Am. Midl. Nat. 137, 266-273.

De la Blache, P.V., 1908. Tableau de la géographie de la France. Hachette.

Dominguez-Rodrigo, M., Serrallonga, J., Juan-Tresserras, J., Alcala, L., Luque, L., 2001. Woodworking activities by early humans: a plant residue analysis on Acheulian stone tools from Peninj (Tanzania). J. Hum. Evol. 40, 289-299.

Estalrrich, A., El Zaatari, S., Rosas, A., 2017. Dietary reconstruction of the El Sidrón Neandertal familial group (Spain) in the context of other Neanderthal and modern hunter-gatherer groups. A molar microwear texture analysis. J. Hum. Evol. 104, $13-22$.

Fagoaga, A., Ruiz-Sánchez, F.J., Laplana, C., Blain, H.A., Marquina, R., Marin-Monfort, M.D., Galván, B., 2017. Palaeocological implications of Neanderthal occupation at Unit Xb of El Salt (Alcoi, eastern Spain) during MIS 3 using small mammals proxy. Quat. Int. http://dx.doi.org/10.1016/j.quaint.2017.10.024.

Finlayson, C., Fa, D.A., Espejo, F.J., Carrión, J.S., Finlayson, G., Pacheco, F.G., Vidal, J.R., Stringer, C., Ruiz, F.M., 2008. Gorham's Cave, Gibraltar - the persistence of a Neanderthal population. Quat. Int. 181, 64-71.

Gale, R., Carruthers, W., 2000. Charcoal and charred seed remains from Middle Palaeolithic levels at Gorham's and Vanguard Caves. In: Stringer, C., Barton, R. Finlayson, C. (Eds.), Neanderthals on the Edge. Oxbow Books, pp. 207-210.

Galván, B., Hernández, C.M., Mallol, C., Machado, J., Sistiaga, A., Molina, F.J., Pérez, L.J., Afonso, R., Garralda, M.D., Mercier, N., Morales, J.V., Sanchis, A., Tarriño, A., Gómez, J.A., Rodríguez, Á., Abreu, I., Vidal-Matutano, P., 2014a. El Salt. Últimos neandertales de la montaña alicantina (Alcoy, España). In: Carbonell, E., Bermúdez de Castro, J.M., Arsuaga, J.L. (Eds.), Los cazadores-recolectores del Pleistoceno y del Holoceno en Iberia y el Estrecho de Gibraltar: Estado actual del conocimiento del registro arqueológico. Universidad de Burgos and Fundación Atapuerca, Burgos, pp. $380-388$.

Galván, B., Hernández, C.M., Mallol, C., Mercier, N., Sistiaga, A., Soler, V., 2014b. New evidence of early Neanderthal disappearance in the Iberian Peninsula. J. Hum. Evol. $75,16-27$.

García Moreno, A., Rios Garaizar, J., Marín Arroyo, A.B., Eugenio Ortíz, J., de Torres, T. López-Dóriga, I., 2014. La secuencia musteriense de la Cueva del Niño (Aýna, Albacete) y el poblamiento neandertal en el sureste de la península Ibérica. Trab. Prehist. 71, 221-241.

Garralda, M.D., Galván, B., Hernández, C.M., Mallol, C., Gómez, J.A., Maureille, B., 2014 Neanderthals from El Salt (Alcoy, Spain) in the context of the latest Middle Palaeolithic populations from the southeast of the Iberian Peninsula. J. Hum. Evol. $75,1-15$.

Goren-Inbar, N., Sharon, G., Melamed, Y., Kislev, M., 2002. Nuts, nut cracking, and pitted stones at Gesher Benot Ya 'aqov, Israel. Proc. Natl. Acad. Sci. 99, 2455-2460.

Gualda Gómez, C.E., 1988. La Sierra de Mariola: aspectos geomorfológicos y biogeográficos. Universidad de Alicante.

Hardy, B.L., Garufi, G.T., 1998. Identification of woodworking on stone tools through residue and use-wear analyses: experimental results. J. Archaeol. Sci. 25, 177-184.

Hardy, B.L., Moncel, M.-H., 2011. Neanderthal use of fish, mammals, birds, starchy plants and wood 125-250,000 years ago. PLoS One 6, e23768.

Hardy, K., Buckley, S., Collins, M., Estalrrich, A., Brothwell, D., Copeland, L., GarcíaTabernero, A., García-Vargas, S., de la Rasilla, M., Lalueza-Fox, C., Huguet, R., Bastir, M., Santamaría, D., Madella, M., Wilson, J., Cortés, Á., Rosas, A., 2012. Neanderthal medics? Evidence for food, cooking, and medicinal plants entrapped in dental 
calculus. Naturwissenschaften 99, 617-626

Haws, J.A., 2004. An Iberian perspective on Upper Paleolithic plant consumption. PRO 2 , 49-106.

Henry, A., Boboeuf, M., 2016. Environnement ligneux et gestion du bois de feu au cours du Mésolithique au Clos de Poujol (Campagnac, Aveyron). In: Bulletin de la Société Préhistorique Française. 113. pp. 5-30.

Henry, A., Théry-Parisot, I., 2014. From Evenk campfires to prehistoric hearths: charcoal analysis as a tool for identifying the use of rotten wood as fuel. J. Archaeol. Sci. 52, 321-336.

Henry, A., Théry-Parisot, I., Voronkova, E., 2009. La gestion du bois de feu en forêt boréale: problématique archéo-anthracologique et étude d'un cas ethnographique (Région de l'Amour, Sibérie). In: Théry-Parisot, I., Costamagno, S., Henry, A. (Eds.), Gestion des combustibles au Paléolithique et au Mésolithique: Nouveaux outils, nouvelles interprétations. Fuel Management during the Palaeolithic and Mesolithic periods: New tools, new interpretations. BAR International Series. 1914. pp. 17-37.

Henry, A.G., Brooks, A.S., Piperno, D.R., 2011. Microfossils in calculus demonstrate consumption of plants and cooked foods in Neanderthal diets (Shanidar III, Iraq; Spy I and II, Belgium). Proc. Natl. Acad. Sci. 108, 486-491.

Hodder, I., Orton, C., 1990. Análisis espacial en Arqueología. Crítica.

Jacquiot, C., Trenard, Y., Dirol, D., 1973. Atlas d'anatomie des bois des angiosperms (Essences feuillues). Paris.

Jarman, M.R., Vita-Finzi, C., Higgs, E.S., 1972. Site catchment analysis in archaeology. In: Ucko, P.J., Tringham, R., Dimbleby, G.W. (Eds.), Man, Settlement and Urbanism. Duckworth, London, pp. 61-66.

Kuhnlein, H.V., Turner, N.J., 1991. Traditional Plant Foods of Canadian Indigenous Peoples. Gordon and Breach Publishers, Amsterdam.

Lev, E., Kislev, M.E., Bar-Yosef, O., 2005. Mousterian vegetal food in Kebara Cave, Mt. Carmel. J. Archaeol. Sci. 32, 475-484.

López Gómez, A., Rosselló Verger, V., 1978. Geografía de la provincia de Alicante. Diputación Provincial de Alicante.

Machado, J., Pérez, L., 2016. Temporal frameworks to approach human behaviour concealed in Middle Palaeolithic palimpsests: a high-resolution example from El Salt Stratigraphic Unit X (Alicante, Spain). Quat. Int. 417, 66-81.

Machado, J., Molina, F.J., Hernández, C.M., Tarriño, A., Galván, B., 2016. Using lithic assemblage formation to approach Middle Palaeolithic settlement dynamics: El Salt Stratigraphic Unit X (Alicante, Spain). Archaeol. Anthropol. Sci. http://dx.doi.org/ 10.1007/s12520-016-0318-z.

Madella, M., Jones, M.K., Goldberg, P., Goren, Y., Hovers, E., 2002. The exploitation of plant resources by Neanderthals in Amud Cave (Israel): the evidence from phytolith studies. J. Archaeol. Sci. 29, 703-719.

Mallol, C., Hernández, C.M., Cabanes, D., Machado, J., Sistiaga, A., Pérez, L., Galván, B., 2013a. Human actions performed on simple combustion structures: an experimental approach to the study of Middle Palaeolithic fire. Quat. Int. 315, 3-15.

Mallol, C., Hernández, C.M., Cabanes, D., Sistiaga, A., Machado, J., Rodríguez, Á., Pérez, L., Galván, B., 2013b. The black layer of Middle Palaeolithic combustion structures. Interpretation and archaeostratigraphic implications. J. Archaeol. Sci. 40, 2515-2537.

Marín Arroyo, A.B., 2008. Patrones de movilidad y control del territorio en el Cantábrico oriental durante el Tardiglaciar. Trab. Prehist. 65, 29-45.

Martínez, C.M., Badal, E., 2018. Plant use at the end of the Upper Palaeolithic: archaeobotanical remains from Cova de les Cendres (Teulada-Moraira, Alicante, Spain). Veg. Hist. Archaeobotany 27 (1), 3-14.

Messager, E., Badou, A., Fröhlich, F., Deniaux, B., Lordkipanidze, D., Voinchet, P., 2010. Fruit and seed biomineralization and its effect on preservation. Archaeol. Anthropol. Sci. 2, 25-34.

Metcalf, C.R., 1964. Gorham's cave, Gibraltar: report on the plant remains. The excavation of Gorham's cave, Gibraltar, 1951-1954. Bull. Inst. Archaeol. 4, 219.

Monasterio-Huelin, E., 1999. Rubus. In: Castroviejo, S., Aedo, C., Laínz, M., Muñoz Garmedia, F., Nieto Feliner, G., Paiva, J., Benedí, C. (Eds.), Flora ibérica 6, pp. 16-71.

Monteiro, P.D., 2013. Wood charcoal analysis of Mesolithic archaeological contexts from Portugal: state of the art. In: ArkeoGazte: Revista de arqueología-Arkelogia aldizkaria. 3. pp. 51-62.

Norman, J., 2004. Running uphill: energy needs and Naismith's Rule. J. Oper. Res. Soc. $55,308-311$.

Ozenda, P., 1982. Les végétaux dans la biosphère. Doin Éditeurs, Paris.

Pardo-de-Santayana, M., Tardío, J., Blanco, E., Carvalho, A.M., Lastra, J.J., San Miguel, E., Morales, R., 2007. Traditional knowledge of wild edible plants used in the northwest of the Iberian Peninsula (Spain and Portugal): a comparative study. J. Ethnobiol. Ethnomed. 3, 27.

Pérez-Díaz, S., López-Sáez, J.A., Ruiz-Alonso, M., Zapata, L., Abel-Schaad, D., 2013. Holocene history of Taxus baccata in the Basque Mountains (Northern Iberian Peninsula). Lazaroa 34, 29-41.

Pryor, A.J., Steele, M., Jones, M.K., Svoboda, J., Beresford-Jones, D.G., 2013. Plant foods in the Upper Palaeolithic at Dolní Vëstonice? Parenchyma redux. Antiquity 87, 971-984.

Richards, M.P., Pettitt, P.B., Trinkaus, E., Smith, F.H., Paunović, M., Karavanić, I., 2000. Neanderthal diet at Vindija and Neanderthal predation: the evidence from stable isotopes. Proc. Natl. Acad. Sci. 97, 7663-7666.

Rios-Garaizar, J., López-Bultó, O., Iriarte, E., Pérez-Garrido, C., Piqué, R., Aranburu, A., Iriarte-Chiapusso, M.J., Ortega-Cordellat, I., Bourguignon, L., Garate, D., Libano, I., 2018. A Middle Palaeolithic wooden digging stick from Aranbaltza III, Spain. PLoS ONE 13 (3), e0195044. http://dx.doi.org/10.1371/journal.pone.0195044.

Rivas-Martinez, S., 1987. Memoria del mapa de series de vegetación de España: 1:400.000. ICONA.
Rivera-Núñez, D., Obón-de-Castro, C., 1991. La Guía de INCAFO de las plantas útiles y venenosas de la Península Ibérica y Baleares (excluidas medicinales). INCAFO, Madrid.

Rodríguez-Cintas, Á., Cabanes, D., 2015. Phytolith and FTIR studies applied to combustion structures: the case of the Middle Paleolithic site of El Salt (Alcoy, Alicante). Quat. Int. http://dx.doi.org/10.1016/j.quaint.2015.09.043.

Roiron, P., Chabal, L., Figueiral, I., Terral, J.-F., Ali, A.A., 2013. Palaeobiogeography of Pinus nigra Arn. subsp. salzmannii (Dunal) Franco in the north-western Mediterranean Basin: a review based on macroremains. Rev. Palaeobot. Palynol. 194, $1-11$.

Roper, D.C., 1979. The method and theory of site catchment analysis: a review. Adv. Archeol. Method Theory 2, 119-140.

Schweingruber, F.H., 1976. Prähistorisches Holz: die Bedeutung von Holzfunden aus Mitteleuropa für die Lösung archäologischer und vegetationskundlicher Probleme. P. Haupt.

Serra Laliga, L., Soler, J., 2011. Flora del Parc Natural de la Font Roja. Caja Mediterráneo, Alcoi.

Shackleton, C.M., Prins, F., 1992. Charcoal analysis and the "Principle of Least Effort"-a conceptual model. J. Archaeol. Sci. 19, 631-637.

Shillito, L.-M., Almond, M.J., 2010. Comment on: fruit and seed biomineralization and its effect on preservation by E. Messager et al. Archaeol. Anthropol. Sci. 2, 225-229.

Sievers, C., 2006. Seeds from the Middle Stone Age layers at Sibudu Cave. South. Afr. Humanit. 18, 203-222.

Sistiaga, A., Mallol, C., Galván, B., Summons, R.E., 2014. The Neanderthal meal: a new perspective using faecal biomarkers. PLoS One 9, e101045.

Snir, A., Nadel, D., Weiss, E., 2015. Plant-food preparation on two consecutive floors at Upper Paleolithic Ohalo II, Israel. J. Archaeol. Sci. 53, 61-71.

Théry-Parisot, I., 2002. Fuel management (bone and wood) during the Lower Aurignacian in the Pataud rock shelter (Lower Palaeolithic, Les Eyzies de Tayac, Dordogne, France). Contribution of experimentation. J. Archaeol. Sci. 29, 1415-1421.

Théry-Parisot, I., Gril, J., Vernet, J., Meignen, L., Maury, J., 1996. Coal used for fuel at two prehistoric sites in southern France: Les Canalettes (Mousterian) and Les Usclades (Mesolithic). J. Archaeol. Sci. 23, 509-512.

Théry-Parisot, I., Chabal, L., Chrzavzez, J., 2010. Anthracology and taphonomy, from wood gathering to charcoal analysis. A review of the taphonomic processes modifying charcoal assemblages, in archaeological contexts. Palaeogeogr. Palaeoclimatol. Palaeoecol. 291, 142-153.

Uzquiano, P., 1992. L'Homme et le bois au Paléolithique en région cantabrique, Espagne. Exemples d'Altamira et d'El Buxu. In: Bulletin de la Société Botanique de France. Actualités Botaniques. 139. pp. 361-372.

Uzquiano, P., Yravedra, J., Zapata, B.R., Garcia, M.J.G., Sesé, C., Baena, J., 2012. Human behaviour and adaptations to MIS 3 environmental trends ( $>53-30 \mathrm{ka} \mathrm{BP}$ ) at Esquilleu cave (Cantabria, northern Spain). Quat. Int. 252, 82-89.

Uzquiano, P., Allué, E., Antolín, F., Burjachs, F., Picornel, L., Piqué, R., Zapata, L., 2015 All about yew: on the trail of Taxus baccata in Southwest Europe by means of integrated palaeobotanical and archaeobotanical studies. Veg. Hist. Archaeobotany 24 229-247.

Vaquero, M., Pastó, I., 2001. The definition of spatial units in Middle Palaeolithic sites: the hearth-related assemblages. J. Archaeol. Sci. 28, 1209-1220.

Vidal-Matutano, P., 2015. Evidència de recol· lecció de teix (Taxus baccata L.) pels grups neandertals de l'Abric del Pastor (Alcoi, Alacant). In: Recerques del Museu d'Alcoi. 24. pp. 7-20.

Vidal-Matutano, P., 2016. Around the Fire: Landscape, Climate and Firewood Management in Hunter-Gatherer Groups during the Middle Palaeolithic (Alicante, Spain). Unpublished Doctoral Dissertation, Universitat de València.

Vidal-Matutano, P., 2017. Firewood and hearths: middle Palaeolithic woody taxa distribution from El Salt, Stratigraphic Unit Xb (Eastern Iberia). Quat. Int. 457, 74-84.

Vidal-Matutano, P., Pardo-Gordó, S., 2017. Modelling Middle Palaeolithic climatic data based on charcoal analysis results: evidence from Abric del Pastor and El Salt (Eastern Iberia). In: 23rd Annual Meeting of the European Association of Archaeologists, 30th August-3rd September 2017, Maastricht. Abstract book., Jos Bazelmans and Klinkhamer Group, pp. 349.

Vidal-Matutano, P., Hernández, C.M., Galván, B., Mallol, C., 2015. Neanderthal firewood management: evidence from Stratigraphic Unit IV of Abric del Pastor (Eastern Iberia). Quat. Sci. Rev. 111, 81-93.

Vidal-Matutano, P., Henry, A., Théry-Parisot, I., 2017a. Dead wood gathering among Neanderthal groups: charcoal evidence from Abric del Pastor and El Salt (Eastern Iberia). J. Archaeol. Sci. 80, 109-121.

Vidal-Matutano, P., Blasco, R., Sañudo, P., Fernández-Peris, J., 2017b. The anthropogenic use of firewood during the European Middle Pleistocene: Charcoal evidence from levels XIII and XI of Bolomor Cave, Eastern Iberia (230-160 ka). Environ. Archaeol. http://dx.doi.org/10.1080/14614103.2017.1406026.

Vita-Finzi, C., Higgs, E.S., 1970. Prehistory economy in the Mount Carmel area of Palestine: site catchment analysis. Proc. Prehist. Soc 36, 1-37.

Weiss, E., Wetterstrom, W., Nadel, D., Bar-Yosef, O., 2004. The broad spectrum revisited: evidence from plant remains. Proc. Natl. Acad. Sci. U. S. A. 101, 9551-9555.

Weiss, E., Kislev, M.E., Simchoni, O., Nadel, D., Tschauner, H., 2008. Plant-food preparation area on an Upper Paleolithic brush hut floor at Ohalo II, Israel. J. Archaeol. Sci. 35, 2400-2414.

Zilhão, J., Ajas, A., Badal, E., Burrow, C., Kehl, M., López-Sáez, J.A., Pimenta, C., Preece, R.C., Sanchis, A., Sanz, M., Weniger, G.-C., White, D., Wood, R., Angelucci, D.E., Villaverde, V., Zapata, J., 2016. Cueva Antón: A multi-proxy MIS 3 to MIS 5a paleoenvironmental record for SE Iberia. Quat. Sci. Rev. 146, 251-273. 